\title{
Significance of germ cells for the expression of testicular endocrine function in rats
}

\author{
F. Kasuga*, K. Shiota and M. Takahashi \\ Laboratory of Veterinary Physiology, Department of Veterinary Science, University of Tokyo, \\ 1-1-1, Yayoi, Bunkyo-ku, Tokyo 113, Japan
}

\begin{abstract}
Summary. Germ-cell depletion was induced in rats by busulphan administration during the fetal period (Group B). Although a sigmoidal increase of serum testosterone concentration was observed $1 \mathrm{~h}$ after the administration of graded doses of $\mathrm{hCG}$ $(0.3-15.0$ i.u. $/ 100 \mathrm{~g}$ body weight) in intact rats and those in Group B, a shift in the dose-response curve to the right was observed in the latter, suggesting that the sensitivity of testicular response to gonadotrophin was lower in germ cell-depleted rats. However, since the sensitivity was almost identical for both groups of rats for isolated Leydig cells incubated in vitro for $3 \mathrm{~h}$ with hCG $(0.5-312.5 \mathrm{i} . \mathrm{u} . / \mathrm{ml})$, the intrinsic nature of the cells was not affected in Group B rats. When the responses of testicular tissue blocks were examined in the in-vitro incubation system, reduced sensitivity reappeared for those from Group B rats, and the presence of testicular tissue components including seminiferous tubules was considered to be responsible for the difference in Leydig cell sensitivity between intact rats and those exposed to busulphan. By the combination of in-vivo and in-vitro experiments, we have demonstrated that germ cells are involved in the endocrine function of the testis.
\end{abstract}

Keywords: germ cell; Leydig cell; testosterone production; sensitivity to hCG; busulphan; rat

\section{Introduction}

Administration of busulphan to male rats has been reported to cause severe degeneration of the germinal epithelium (Vanhems \& Bousquet, 1971; Gomes et al., 1973; Hall \& Gomes, 1973; Tence \& Drosdowsky, 1976; Viguier-Martinez et al., 1984). Testosterone production is lower in busulphan-treated rats while the LH concentration is higher, suggesting that the responsiveness of Leydig cells to gonadotrophin is reduced (Kasuga \& Takahashi, 1986). Furthermore, we noted that the cessation of spermatogenesis preceded an increase in the serum LH value and a decrease in the serum testosterone concentration (Kasuga \& Takahashi, 1986). The timing of this change in the germ cells suggests that the cessation of spermatogenesis might alter the testicular endocrine function in male rats. In female rats, when the influence of germ cells was removed by exposing rats to busulphan in the fetal period, ovarian cells became simple oestrogen-secreting cells, which did not luteinize in response to hCG (Kasuga \& Takahashi, 1986; Takahashi et al., 1989), suggesting that germ cells play a role in the steroidogenesis and differentiation of ovarian endocrine cells.

Spermatogenesis is under the control of pituitary hormones, and androgen is essential for its initiation and maintenance. LH stimulates spermatogenesis via the production of testosterone from Leydig cells, FSH acts on spermatogenesis through the production of proteins such as androgenbinding protein (ABP) from Sertoli cells (Steinberger \& Steinberger, 1977; Ritzen, 1983), and

\footnotetext{
*Present address: Department of Biomedical Research on Foods, National Institute of Health, 2-10-35 Kamiosaki, Shinagawa-ku, Tokyo 141, Japan.
} 
prolactin plus testosterone also stimulate spermatogenesis (Shiota et al., 1981). There have been many reports on the mechanism of androgen production by gonadotrophins, and the actions of $\mathrm{LH}$ and hCG are well documented at the cellular or molecular level (Dehejia et al., 1982). Some information has been provided on factors which are produced by seminiferous tubules and modulate Leydig cell functions (Syed et al., 1985; Verhoeven \& Cailleau, 1985, 1987). However, the biological effects of germ cells on Leydig cells have not yet been clarified.

In the present study, the responses of testosterone secretion to hCG in intact and busulphantreated rats were compared using in-vivo and in-vitro methods, and the role of germ cells in testicular endocrine function was studied.

\section{Materials and Methods}

Animals. Wistar rats bred in our laboratory were maintained on a commercial diet and tap-water ad libitum under a light regimen of $14 \mathrm{~h}$ light (05:00-19:00 h) and $10 \mathrm{~h}$ darkness.

Busulphan treatment. A female rat was placed with a fertile male on the evening of pro-oestrus, and the day of sperm detection in vaginal smears was designated as Day 1 of pregnancy. On Day 15 of pregnancy, the dam received an i.p. injection of $10 \mathrm{mg}$ busulphan/ $\mathrm{kg}$ body weight (1,4-dimethanesulphonoxybutane; Takeda Chemical Industries, Ltd, Osaka, Japan), which was finely suspended in sesame oil. Male offspring that had been thus treated with busulphan in the fetal period (Group B) and normal male rats (Group C) were used for the present experiments at 3-4 months of age.

Response to hCG in the testis in vivo. Rats in Groups B and C (3-5 rats per group) were injected with $0 \cdot 3,3 \cdot 0$ or 15.0 i.u. hCG $/ 100 \mathrm{~g}$ body weight (Teikoku-Zoki, Co. Ltd, Tokyo, Japan) each in $0.1 \mathrm{ml} 0.15 \mathrm{M}-\mathrm{NaCl}$ into the femoral vein under ether anaesthesia. Blood samples were collected from both groups by heart puncture $0.5,1$ and $3 \mathrm{~h}$ after the hCG injection, serum was obtained by centrifugation $(2000 \mathrm{~g}$ for $10 \mathrm{~min})$ and the samples stored at $-20^{\circ} \mathrm{C}$ until extraction.

Preparation of Leydig cells. Leydig cells were obtained by the method of Dufau et al. (1974). Six decapsulated testes from each group of rats were incubated in a capped polypropylene tube containing $10 \mathrm{ml}$ MEM (pH 7.4) with $1 \mathrm{mg}$ bovine serum albumin (BSA)/ml and $0.25 \mathrm{mg}$ collagenase $/ \mathrm{ml}$ (CLS II, Worthington, Freehold, NJ, USA) at $37^{\circ} \mathrm{C}$ for $15 \mathrm{~min}$ with shaking. After the incubation, the tube was stood vertically for $5 \mathrm{~min}$ at room temperature. The supernatant was decanted into a polypropylene tube and the seminiferous tubules were washed once with $10-20 \mathrm{ml}$ MEM $-0 \cdot 1 \%$ BSA. The supernatants were combined, filtered through nylon gauze, and centrifuged at $200 \mathrm{~g}$ for $5 \mathrm{~min}$. After the sedimented cells had been washed twice with $20 \mathrm{ml}$ MEM-0.1\% BSA, the cells were counted and resuspended in MEM-0.1\% BSA at $1 \times 10^{6} \mathrm{cells} / \mathrm{ml}$.

Response of isolated Leydig cells to hCG in vitro. Incubations were performed in 24-well dishes (Nunc; each well $1.5 \mathrm{~cm}$ in diameter) at $37^{\circ} \mathrm{C}$ under an atmosphere of $95 \% \mathrm{O}_{2}: 5 \% \mathrm{CO}_{2}$. All experiments were performed in duplicate. Each well contained $1.0 \mathrm{ml}$ Leydig cell suspension in MEM-0.1\% BSA (pH 7.4) and $0.1 \mathrm{ml}$ hCG solution at $0.5-312.5 \mathrm{mi} . \mathrm{u} . / \mathrm{ml}$. At $3 \mathrm{~h}$ after the incubation, the cell suspensions were centrifuged at $2000 \mathrm{~g}$ for $10 \mathrm{~min}$, and the supernatants were collected.

Response of testicular tissue blocks to hCG in vitro. Four decapsulated testes from Group C or Group B rats were cut into 16 blocks. Each testicular tissue block was incubated in $5 \mathrm{ml}$ MEM-0.1\% BSA (pH 7.4) containing hCG (20-2000 mi.u. $/ \mathrm{ml}$ ). The incubation was performed in quadruplicate in capped polypropylene tubes at $37^{\circ} \mathrm{C}$ for $3 \mathrm{~h}$ with shaking. After the incubation, medium was collected and the supernatants were obtained by centrifugation $(2000 \mathrm{~g}$ for $10 \mathrm{~min}$ ).

Steroid extraction and RIA. Testosterone was extracted from the serum or medium with diethyl ether and assayed by RIA by the method of Maroulis \& Abraham (1975). The antiserum was raised in a rabbit against $11 \alpha$-hydroxytestosterone 11-hemisuccinate-bovine serum albumin in our laboratory, and was used at a final dilution of 1/18 000. The minimum sensitivity of the method was $50 \mathrm{pg}$ testosterone and the coefficient of variation for duplicate samples ranged from 8 to $13 \%$ according to the level assayed. Samples from one kind of experiment were measured in the same assay.

Statistical analysis. Analysis of variance was used to determine the significance of treatment effects, treatment group means were then compared with those for normal rats using Dunnett's 2-tailed $t$ test. 


\section{Results}

\section{Organ weights and testicular histology of Group B rats}

In Group B rats, increase of testicular weight was retarded on Day 20 compared with that in Group C rats, and stopped by Day 50; the testicular weight remained around $350 \mathrm{mg}$. On the other hand, weight of the ventral prostate increased constantly in Group B rats without the acute growth which was seen in normal rats after Day 40.

In Group B testes, tubular structures and Leydig cells were formed, and the start of meiosis was observed on Day 20, although the number of germ cells and the frequency of division were far smaller than in Group C rats. By Day 50, most germ cells had disappeared from the seminiferous tubules of Group B rats. The number of Leydig cells per testis was relatively similar in the two groups of rats according to multiplication of the number per unit area under the microscope by the weight of the testis ( 73 in Group C, 77 in Group B). Total number of Leydig cells was not changed by busulphan treatment.

\section{Time-course of testosterone production in response to hCG administration in vivo}

Rats were injected intravenously with $15.0 \mathrm{i} . \mathrm{u}$. hCG/100 g body weight, and serum concentrations of testosterone at $0 \cdot 5,1$ and $3 \mathrm{~h}$ after injection are shown in Fig. 1. In both groups of rats, testosterone concentrations reached maximum $1 \mathrm{~h}$ after the injection and declined after $3 \mathrm{~h}$.

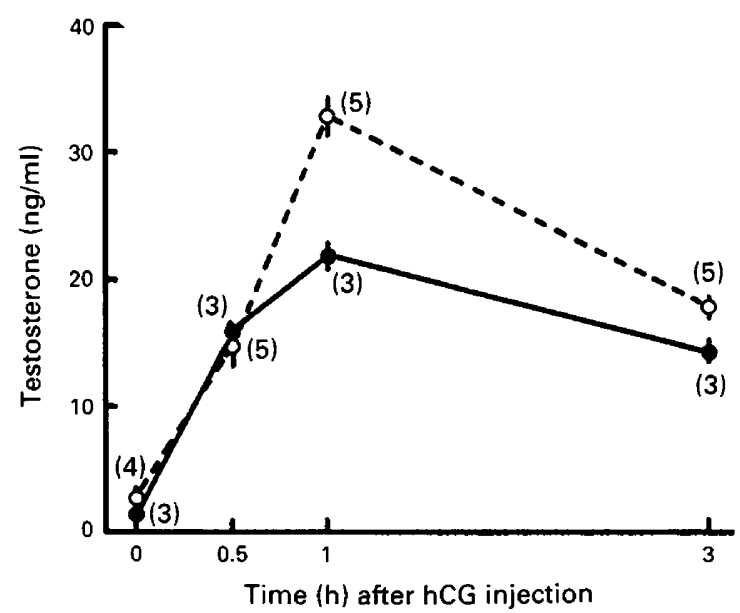

Fig. 1. Changes in serum testosterone concentrations after administration of hCG. Rats in Group C ( $\bigcirc$, control) and Group B ( $\odot$, busulphan) were injected i.v. with $15 \cdot 0$ i.u. hCG $/ 100 \mathrm{~g}$ body weight. Values are mean \pm s.e. for the no. of animals indicated in parentheses.

\section{Response of the testis to hCG in vivo}

Serum testosterone concentrations in both groups of rats $1 \mathrm{~h}$ after i.v. injection of various doses of hCG were measured. To compare the responsiveness to hCG between the two groups, the relative values of testosterone against the basal level were plotted (Fig. 2). Either 0.3 or $3 \mathrm{i} . \mathrm{u}$. hCG $/ 100 \mathrm{~g}$ body weight was required to induce a minimal but significant response, and 3 or 15 i.u. hCG $/ 100 \mathrm{~g}$ body weight were required to induce a maximal response in Group $\mathrm{C}$ and Group $B$ rats, respectively. The dose-response curve was shifted to the right in Group B rats, indicating a decrease in the sensitivity of testosterone production in response to hCG stimulation in those rats in vivo. 


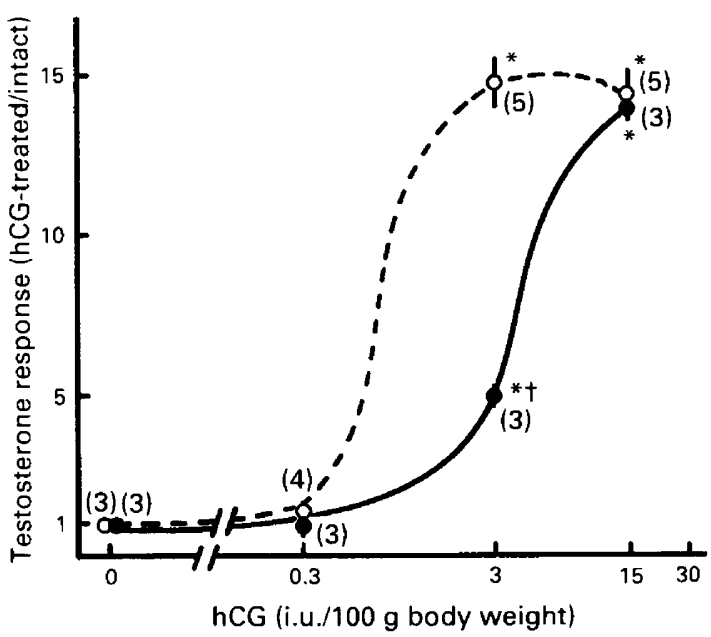

Fig. 2. Testosterone secretion in rats in Group $\mathrm{C}(\mathrm{O}$, control) and Group B ( $\bullet$, busulphan) in response to various doses of hCG in vivo. Serum concentrations of testosterone were measured $1 \mathrm{~h}$ after i.v. injection of hCG. Values are mean \pm s.e. relative to basal for the no. of animals indicated in parentheses. ${ }^{*} P<0.01$ compared with basal value; $\dagger P<0.01$ compared with value for Group $\mathrm{C}$ rats at this dose.

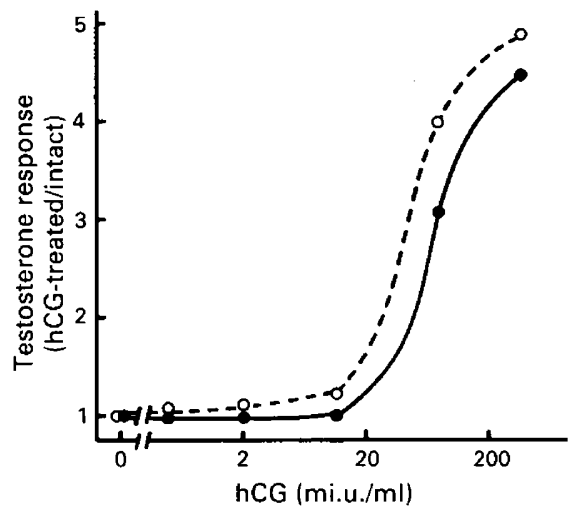

Fig. 3. Testosterone secretion in response to hCG in vitro by Leydig cells isolated from rats in Group C ( $\bigcirc$, control) and Group B ( $\bullet$, busulphan) and pooled ( 6 testes from 3 rats/group). Each point represents the average of duplicate assays of the value relative to the basal level.

\section{Response of isolated Leydig cells to hCG in vitro}

To clarify whether the difference of sensitivity to hCG in the testes of rats in the two groups was due to the Leydig cells themselves, isolated Leydig cells were incubated with or without various doses of hCG for $3 \mathrm{~h}$ in vitro. The response of testosterone secretion was defined as the ratio to the basal testosterone concentration when Leydig cells were incubated without hCG. The patterns of increase in the response to $\mathrm{hCG}$ up to $312.5 \mathrm{mi} . \mathrm{u} . / \mathrm{ml}$ in rats in Group B and C were almost the same (Fig. 3). The intrinsic property of Leydig cells in Group B rats was therefore the same as that of Leydig cells in Group C rats, and the difference in sensitivity to hCG observed in vivo was not due to the Leydig cells themselves. 


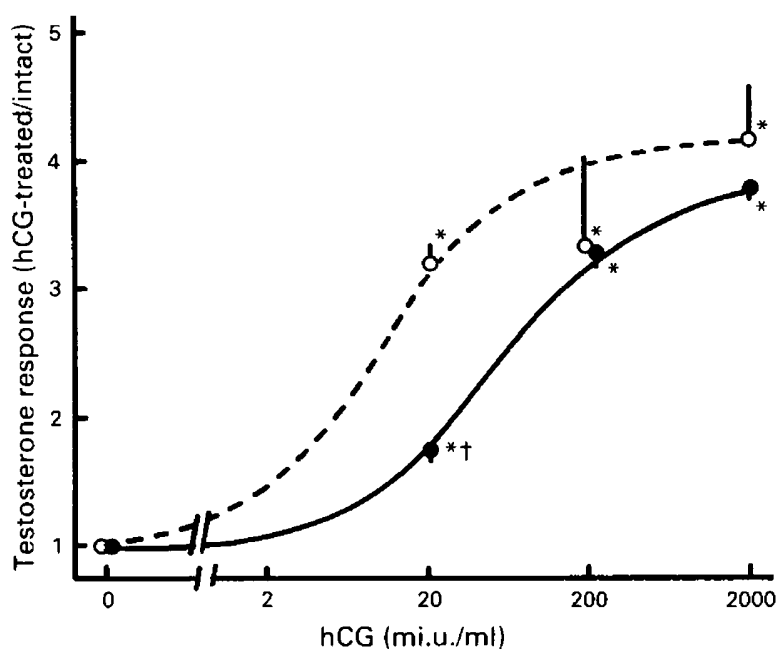

Fig. 4. Testosterone secretion by testicular tissue blocks from rats in Group $\mathrm{C}(\mathrm{O}$, control) and Group B (, , busulphan) in response to hCG in vitro. Four blocks from 4 rats/group were used with each dose of hCG: values are mean \pm s.e. relative to the basal level. $* P<0.01$ compared with basal value; $\uparrow P<0.01$ compared with value for Group $C$ rats at this dose.

Table 1. Summary of the role of germ cells in testicular steroidogenesis in rats

\begin{tabular}{lccccc}
\hline & & \multicolumn{4}{c}{ Components } \\
\cline { 3 - 5 } & Group & $\begin{array}{c}\text { Germ } \\
\text { cell }\end{array}$ & $\begin{array}{c}\text { Sertoli } \\
\text { cell }\end{array}$ & $\begin{array}{c}\text { Leydig } \\
\text { cell }\end{array}$ & $\begin{array}{c}\text { Sensitivity } \\
\text { to hCG* }\end{array}$ \\
\hline In vivo & C & + & + & + & $(+++)$ \\
& B & - & + & + & $(+)$ \\
\hline In vitro & C & + & + & + & +++ \\
Tissue block & B & - & + & + & + \\
Isolated cell & C & - & - & + & + \\
& B & - & - & + & + \\
\hline
\end{tabular}

*The sensitivity was expressed according to the response to a submaximal effective dose of hCG (for details, see Figs 2, 3 and 4).

Response of the testicular tissue blocks to hCG in vitro

A sub-maximal testosterone response was obtained with $20 \mathrm{mi} . \mathrm{u}$. hCG/ml in Group C, while only a slight response was observed with this dose in Group B rats when testicular tissue blocks were used (Fig. 4). A shift of the dose-response curve to the right was therefore observed, and the sensitivity was lower in Group B.

The response of testosterone secretion is summarized in Table 1. The sensitivity of isolated cells was almost the same in Group C and Group B rats, whereas in the tissue blocks the response was lower for Group B. When the response of isolated cells and that of tissue blocks were compared, the sensitivities of both experimental systems were almost the same for Group B rats, whereas in Group $C$ rats there was an evident improvement when tissue blocks were used. The difference of sensitivity observed in the tissue blocks from both groups of rats therefore seemed to depend on the difference resulting from the augmentative activity of seminiferous tubules. 


\section{Discussion}

The present study confirmed our previous findings (Kasuga \& Takahashi, 1986), which suggested reduced sensitivity to gonadotrophins in the testis of busulphan-treated rats. However, isolated Leydig cells showed no difference in their sensitivity for steroid production. Therefore, the difference in sensitivity observed in vivo was not due to an alteration in the intrinsic nature of Leydig cells by the busulphan treatment, but rather to a difference in influence from other components of the testis. Since a reduction of sensitivity to hCG was again observed in vitro using the testicular tissue blocks, and since almost the same number of Leydig cells was contained in the blocks of the two groups, germ cells appeared to be the component affecting sensitivity of the Leydig cells to pituitary hormone.

Interestingly, the responses of testosterone secretion were the same among the studies using tissue blocks from busulphan-treated rats and isolated Leydig cells from both groups. Therefore, the seminiferous tubules from intact rats seemed to increase the sensitivity to hCG, while those from busulphan-treated rats did not seem to decrease the sensitivity. The reduced sensitivity of isolated cells from rats of both groups might have been due to non-specific damage of the cells by the prior enzymic treatment. This seems unlikely, however, since the sensitivity of both cells and tissue blocks from busulphan-treated rats would have been identical.

Rich \& de Kretser (1977) and Rich et al. (1979) noticed decreased testosterone secretion in response to hCG in testes with germ-cell depletion induced by hydroxyurea treatment, vitamin $\mathrm{A}$ deficiency, or fetal irradiation in utero, and they speculated that seminiferous tubules might produce some inhibitory substance(s). Our results suggested that the reduced sensitivity of the Leydig cells in these animals might be due to a lack of augmentative effect of germ cells on the seminiferous tubules.

A decrease in the number of LH receptors per Leydig cell has been demonstrated in X-irradiated rats (Rich \& de Kretser, 1979) and busulphan-treated rats (Viguier-Martinez et al., 1984). It seems likely that the change in LH receptor is responsible for the reduction of the sensitivity to hCG in the testis of busulphan-treated rats.

Germinal epithelium forms spermatogenic waves associated with cyclic variations in sperm maturation (Perey et al., 1961) and Sertoli cell functions (Parvinen, 1982; Ritzen, 1983). As previously demonstrated (Ireland \& Welsh, 1987; Janecki et al., 1988; Pinon-Lataillade et al., 1988), germ cells regulate some of the functions of Sertoli cells. Since testosterone has an essential role in several steps of spermatogenesis, the modulation of testosterone production by the presence of germ cells must be involved in the process of spermatogenic wave formation. The disappearance of germ cells may also be involved in the reduction of steroidogenic activity observed in surgically cryptorchid animals, because in most of the cases the decrease in peripheral blood concentration of testosterone was observed after the degeneration of the germinal epithelium which occurs 10 days after the treatment (Inano \& Tamaoki, 1968; Amatayakul et al., 1971; Swerdloff et al., 1971).

In relation to the spermatogenic wave, the morphological and functional heterogeneity of Leydig cells depending upon the spermatogenic stage of the most adjacent seminiferous tubule has been shown (Bergh, 1982). In the present study, isolated Leydig cells from busulphan-treated rats had the same sensitivity to hCG as those from control rats. The functional heterogeneity of Leydig cells was not retained under our present in-vitro conditions.

It has been demonstrated that the spent medium obtained from seminiferous tubules at different stages has different modifying influences on testosterone secretion from Leydig cells (Parvinen et al., 1984; Syed et al., 1985). Verhoeven \& Cailleau (1985, 1987) characterized a Leydig cell stimulatory factor produced from rat Sertoli cell-enriched cultures and human tubular fragments. There have been some other descriptions of Leydig cell-modulating factors (Sharpe, 1984; Perrard-Sapori et al., 1987; Carreau et al., 1988). Such short-lived substances may therefore be responsible for the modulation of Leydig-cell activity by germ cells. However, whether those factors are operating in vivo has not yet been shown. The present work, using a combination of 
in-vivo and in-vitro procedures, shows that there is a modulating effect of germ cells on Leydig cell function.

This work was supported by a grant (No. 61790241) from the Ministry of Education, Science and Culture of Japan.

We thank Takeda Chemical Industries Ltd, for generously providing the busulphan; Dr S. Kumagai at NIH of Japan for instructive discussion; and Dr D. B. Douglas for proof reading.

\section{References}

Amatayakul, K., Ryan, R., Uozumi, T. \& Albert, A.A. (1971) A reinvestigation of testicular-anterior pituitary relationships in the rat. I. Effects of castration and cryptorchidism. Endocrinology 88, 872-880.

Bergh, A. (1982) Local differences in Leydig cell morphology in the adult rat testis: Evidence for local control of Leydig cells by adjacent seminiferous tubules. Int. J. Androl. 5, 325-330.

Carreau, S., Papadopoulos, V. \& Drosdowsky, M.A. (1988) Stimulation of adult rat Leydig cell aromatase activity by a Sertoli cell factor. Endocrinology 122 , 1103-1109.

Dehejia, A., Nozu, K., Catt, K.J. \& Dufau, M.L. (1982) Luteinizing hormone receptors and gonadotropic activation of purified rat Leydig cells. J. biol. Chem. 257, 13781-13786.

Dufau, M.L., Mendelson, R. \& Catt, K.J. (1974) A highly sensitive in vitro bioassay for luteinizing hormone and chorionic gonadotropin: testosterone production by dispersed Leydig cells. J. clin. Endocr. Metab. 39, 610-613.

Gomes, W.R., Hall, R.W., Jain, S.K. \& Boots, L.R. (1973) Serum gonadotropin and testosterone levels during loss and recovery of spermatogenesis in rats. Endocrinology 93, 800-809.

Hall, R.W. \& Gomes, W.R. (1973) Testosterone levels in the serum and testes of growing rats following prenatal exposure to busulphan. J. Reprod. Fert. 35, $131-134$.

Inano, H. \& Tamaoki, B. (1968) Effect of experimental bilateral cryptorchidism on testicular enzymes related to androgen formation. Endocrinology 83, 1074-1082.

Ireland, M.E. \& Welsh, M.J. (1987) Germ cell stimulation of Sertoli cell protein phosphorylation. Endocrinology 120, 1317-1326.

Janecki, A., Jakubowiak, A. \& Steinberger, A. (1988) Effect of germ cells on vectorial secretion of androgen binding protein and transferrin by immature rat Sertoli cells in vitro. J. Androl. 9, 126-132.

Kasuga, F. \& Takahashi, M. (1986) The endocrine function of rat gonads with reduced number of germ cells following busulphan treatment. Endocrinol. Jpn. 33, $105-115$.

Maroulis, G.B. \& Abraham, G.E. (1975) Radioimmunoassay for $20 \alpha$-dihydroprogesterone. Analyt. Letters 8 , $437-441$.

Parvinen, M. (1982) Regulation of the seminiferous epithelium. Endocrine Rev. 3, 404-417.

Parvinen, M., Nikula, H. \& Huhtaniemi, I. (1984) Influence of rat seminiferous tubules on Leydig cell testosterone production in vitro. Molec. cell. Endocrinol. 37, 331-336.
Perey, B., Clermont, Y. \& Leblond, C.P. (1961) The wave of the seminiferous epithelium in the rat. Am. J. Anat. 108, 47-77.

Perrard-Sapori, M.H., Chatelain, P.C., Rogemond, N. \& Saez, J.M. (1987) Modulation of Leydig cell functions by culture with Sertoli cells or with Sertoli cell-conditioned medium: effect of insulin, somatomedin-C and FSH. Molec. cell. Endocrinol. 50, 193-201.

Pinon-Lataillade, G., Velez de la Calle, J.F., ViguierMartinez, M.C., Garnier, D.H., Folliot, R., Mass, J. \& Jegou, B. (1988) Influence of germ cells upon Sertoli cells during continuous low-dose rate $\gamma$-irradiation of adult rats. Molec. cell. Endocrinol. 58, 51-63.

Rich, K.A. \& de Kretser, D.M. (1977) Effect of differing degrees of destruction of the rat seminiferous epithelium on levels of serum follicle stimulating hormone and androgen binding protein. Endocrinology 101, 959-974.

Rich, K.A. \& de Kretser, D.M. (1979) Effect of fetal irradiation on testicular receptors and testosterone response to gonadotrophin stimulation in adult rats. Int. J. Androl. 2, 343-352.

Rich, K.A., Kerr, J.B. \& de Kretser, D.M. (1979) Evidence for Leydig cell dysfunction in rats with seminiferous tubule damage. Molec. cell. Endocrinol. $13,123-125$.

Ritzen, E.M. (1983) Chemical messengers between Sertoli cells and neighbouring cells. J. Steroid Biochem. 19, 499-504.

Sharpe, R.M. (1984) Intratesticular factors controlling testicular function. Biol. Reprod. 30, 29-40.

Shiota, K., Takahashi, M. \& Suzuki, Y. (1981) Testicular function of actively immunized male rats with $\mathrm{LH}$ releasing hormone (LHRH): a possible role of prolactin on regulation of spermatogenesis. Endocrinol. Jpn. 28, 521-534.

Steinberger, A. \& Steinberger, E. (1977) The Sertoli cells. In The Testis, vol. 4, pp. 371-399. Eds A. D. Johnson \& W. R. Gomes. Academic Press, New York.

Swerdloff, R.S., Walsh, P.C., Jacobs, H.S. \& Odell, W.D. (1971) Serum LH and FSH during sexual maturation in the male rat: effect of castration and cryptorchidism. Endocrinology 88, 120-128.

Syed, V., Khan, S.A. \& Ritzen, E.M. (1985) Stage-specific inhibition of interstitial cell testosterone secretion by rat seminiferous tubules in vitro. Molec. cell. Endocrinol. 40, 257-264.

Takahashi, M., Kasuga, F., Saito, S., Matsuyama, S., Yamanouchi, K., Murata, T. \& Shiota, K. (1989) Role of germ cells and splenocytes in the steroidogenesis of ovarian endocrine cells. In Development of 
Pre-implantation Embryos and their Environment, pp. 101-115. Eds K. Yoshinaga \& T. Mori. Alan Liss, Inc., New York.

Tence, M. \& Drosdowsky, M. (1976) Biosynthesis and metabolism of testosterone by Sertoli cell-enriched seminiferous tubules. Biochem. Biophys. Res. Commun. 73, 47-55.

Vanhems, E. \& Bousquet, J. (1971) Influence du Misulban sur le developpement de l'ovaire du rat. Annls Endocrinol. 32, 753-761.

Verhoeven, G. \& Cailleau, J. (1985) A factor in spent media from Sertoli cell-enriched cultures that stimu- lates steroidogenesis in Leydig cells. Molec. cell. Endocrinol. 40, 57-68.

Verhoeven, G. \& Cailleau, J. (1987) A Leydig cell stimulatory factor produced by human testicular tubules. Molec. cell. Endocrinol. 49, 137-147.

Viguier-Martinez, M.C., de Reviers, M.T.H., Barenton, B. \& Perreau, C. (1984) Effect of prenatal treatment with busulphan on the hypothalamo-pituitary axis, genital tract and testicular histology of prepubertal male rats. J. Reprod. Fert. 70, 67-73.

Received 14 December 1988 